\title{
The Mongol Invasions of Central Asia
}

\author{
Arshad Islam
}

\begin{abstract}
The Mongol invasions of Central Asia were the greatest catastrophe in the history of Islamic civilization, laying waste to the global centre of intellectual achievement during the $11^{\text {th }}$ to $13^{\text {th }}$ centuries. The classical Islamic civilization of the dawlatayn (Umayyad and Abbasid dynasties) had continued in one form or another into the early $12^{\text {th }}$ century, supporting the famous blossoming of culture and science which gave birth to the modern world during the European Renaissance. This paper explores the causes and consequences of the Mongol invasions based on Persian, Arabic, Urdu and English sources. It finds that the Mongols were dismissed by the Muslim elite in Central Asia, particularly the Khwarazm Shah and his court, as a barbaric horde that posed no significant threat to them. It finds that the sophisticated system of Mongol propaganda was so effective that the myths it propagated are widely believed to this day, with emotive imagery such as the Tigris running red with the blood of the Muslims and black with the ink of their scholars, as Chengis Khan and his successors unleashed an unstoppable force of nature to destroy civilization. Conversely, the study concludes that the causes of the Mongol invasions were more related to the weaknesses and incompetence of the Central Asian civilization than to the inherent strength of the Mongol invaders, and furthermore that the Islamic civilization was already waning before their arrival in Otrar. It concludes that the Mongol invasions, although initially catastrophic for Central Asia, as with most invasions, ultimately led to the integration of the Mongols into Islamic civilization (like the Ghaznavids and Seljuqs before them) and gave a new impetus to life and culture in the region later expressed in the Timurids and Mughals. It finds that the Mongols represented a later manifestation of the ancient phenomenon of nomadic invaders of decadent civilizations giving a new course and direction to the latter, as recognised in 'pre-Islamic' Persian sources and identified in Islamic sociology by Ibn Khaldun.
\end{abstract}

Index Terms - Umayyads, Abbasids, Mongols, Chengis Khan, Khwarazm Shah, Ghaznavids, Seljuqs.

\section{INTRODUCTION}

The region of Central Asia is located in the meeting place of Europe and Asia, extending from the countries of the Eastern Mediterranean to China, between Russia to the north and Iran, Afghanistan and India in the south. The region consists of the modern republics of Uzbekistan, Kazakhstan, Tajikistan, Turkmenistan and Kyrgyzstan [1]. Historically it has always been populated by sedentary cultivators and Turkic nomads. Following its annexation by Cyrus the Great (580-529 BCE) during the Achaemenid Empire (648-330 $\mathrm{BCE}$ ), the region was successively controlled by the Saka nomads and Hunnic invaders before becoming part of the Indo-Buddhist Kushan Empire. Ardashir I, the founder of the

Manuscript received September 26, 2014; revised December 30, 2014.

Arshad Islam is with the Department of History \& Civilization International Islamic University, Malaysia (e-mail: arshadislam2@gmail.com).
Sassanid Empire (226-650 CE), captured the region c. 227. The Sassanids' frontiers were persistently threatened by the Huns until Khusrau Anushirvan (531-579 CE) definitively crushed them in 559 in alliance with western Turks [2].

The Muslims initially encountered Transoxiana in pursuit of the fleeing Sassanid authorities, including Yezdigird (632-651), as the latter attempted to muster a counter offensive in collaboration with regional and Chinese forces. Central Asia subsequently became an economically important zone of the Umayyad Empire (661-750). Large-scale conversion made it central in Arab-Islamic intellectual and political life, but the rapacious taxation policies of the Umayyads led to the region promoting the Abbasid revolution in 750 [3]-[6]. Under the Abbasid dynasty (750-1258) the region was increasingly independent following the policy of provincial autonomy accelerated by Harun al-Rashid, paving the way for semi-independent Muslim dynasties including the Tahirids (821-873), the Saffarids (861-1003) and the Samanids (874-999). Classical Islamic culture, including the core Islamic science of hadith (traditions of the Prophet Muhammad [pbuh], upon which Sunni jurisprudence is based) as well as mathematical and medicinal learning, is virtually synonymous with Central Asia. It is unclear how exactly the region came to witness large-scale conversion; fragmentary accounts of the ceremonial burning of the native idols in Samarqand by the Umayyad general Qutaybah bin Muslim hardly suffice to explain the remarkable intellectual contribution of the inhabitants to Islamic civilization, but it can be inferred that astute cultural adaptations, such as allowing the Qur'an to be recited in Persian translation in Bukhara and Samarqand, enabled the common people (and more importantly the Persian-speaking intelligentsia) to understand and engage with the Islamic message. This process was fundamentally facilitated by the Abbasid concession of semi-autonomy and the cultural patronage of the Samanid governors [7].

The region was also military important, both in internal affairs (e.g. Al-Ma'mun seized the Caliphate with armies from Khurasan in 813) and as a buffer zone between the nomadic tribes of Inner Asia and the sedentary Islamic civilization to the south. In the latter regard it functioned as a conduit for the absorption of restive Turkic tribes, incorporating them into the framework of Islamic governance in the local periphery (e.g. the Ghaznavids and Khwarezmids) and in the Iraqi centre (e.g. Al-Mu'tasim [r. 833-842] recruited Turks to his central army, consolidating Abbasid rule in Iraq and leading to an urban boom, such as the development of Samarra as a garrison town for the Turkish soldiers). As a result, Islam gained strong support among the Turkish tribes, who became more integrated into sedentary civilization for the first time [8], [9]. 


\section{A. Origin of the Mongols}

Before discussing the Mongol mayhem to the Islamic civilization of Central Asia we should aware about the early history of Mongols and the rise of Chengis Khan to power. According to Chu Hsi, Tung-kian-kang-mu, the name 'Mongol' was unfamiliar in the world history until the late Tang (619-907) period. Rashiduddin Fadlullah in Jamiut Tawarikh asserts that Siberia was populated by 'Turks' including the Mongol, Chalair, Tatar, Kirghiz, Kunghurat and Aroulad clans. The Mongol nation (Shubah-i-Mughul) was considered one among many 'Turkish peoples' (Aqwam-i-Atrak), but later the prowess and grandeur of the Mongols led to all other Turkish tribes being identified with them and thus being referred to as 'Tatars' [10]-[12].

\section{B. Birth of Temuchin}

According to Muslim historians Temuchin was born on the 20th Zilqadah 540/ 22 January 1155; some other traditions assert that he was born on 9th Zilhijjah 540/ 22 May 1146 in the cycle year of boar or Hog (Tankuz) at the foot of the Deliun-Boldak on the bank of the Onon. He was born to Yesugai Bahadur and his wife Oyelun/Yassuka Khatun, from the Borgin clan of Mongols and the Unggirat tribe, respectively. Temuchin was named after the chieftain Temuchin Uka, vanquished by his father [11]-[14].

At the age of nine Temuchin married Bortei, a ten year-old of the Olkhuna tribe in order to find a wife for him. Following the poisoning of his uncle by the Tatars, Temuchin became the heir of the Borgigan clan in 1166-67 CE, at the age of 11 . Due to his youth many tribesmen refused to acknowledge him and the clan diminished in relative importance. Rival clans stole their livestock and the Markit tribe kidnapped Bortei for many years; she was recovered during the subsequent campaigns of Chinggis in which he unified the Naimans, Markits, Uighurs, Tartars and Keraits by $1206 \mathrm{CE}$ [15], [16].

\section{The Mongol InVAsion of Central Asia}

The disintegration of Seljuq governance in the 12th century led to a resurgence of the embittered Abbasids (who had been reduced to ceremonial status) and the rise of the local Khwarezmid dynasty in Central Asia. As the latter refused to capitulate to Abbasid authority there was great hostility between the Abbasid Caliph Al-Nasir (1180-1225) and the Khwarazm-Shah Ala-ad-Din Muhamad II, including the former hiring the Kara-Khitai (Turkic nomads) to attack the Khwarazm-Shah and instigating a campaign of political assassination; thus the Muslim east was in disarray and disunity at the onset of the Mongol encounter with Central Asia.

The Mongol invasions of the early thirteenth century CE were among the most significant events in world history. The Mongol conquest of Central Asia opened the way for the advance of the Mongol hordes into the rest of the Muslim world and Europe, leading to the sack of Baghdad and fundamentally altering the course of Islamic history.

Early expeditions into Eastern Turkestan by the Mongols started as early as 1207 , and a punitive action against the Kara-Khitai was the prelude to the all-out Mongol invasion of Central Asia in 1218-1219. Sultan $\square$ Alaad-Din Muhammad, the Khwarazm-Shah, was by then aware of the turbulence in the Turkic belt to the north, and he pre-emptively challenged and defeated the small Mongol punitive force against the Kara-Khitai. Subsequent efforts at diplomacy by the Mongols failed to prevent war, and in the meantime a caravan of merchants from the Mongol Empire was butchered at Otrar on the orders of the Khwarezmid governor. This political event accelerated the Mongol attack of Central Asia, which proved to be the greatest nakba then encountered by the Central Asian Muslims. John Andrew Boyle, the renowned scholar, divided the Mongol invasion and occupation of Central Asia into three phases: the first phase (1206-1227) concerning Chengis Khan and the conquest of the Khwarezmid Sultanate; the second of consolidation and growth under Ogedai (1229-1241); and the third of the Pax Mongolica under Mongke Khan (1251-1259) and Qubilai Khan (1260-1294) [17]-[22].

The Mongol invasions are notorious to all Muslims because of the popular misconception that the Mongols signified an irresistible and indomitable power that was beyond the Muslims' capability to challenge. The Mongols themselves anticipated a ruinous and costly campaign, and were surprised by the ease with which Central Asia fell to their control. It was the demoralization and lack of effective leadership among the Muslims that forced them to retreat, and the Islamic civilization later overcame greater odds in the battle of Ayn Jalut in 1260 [23].

It was thus a number of factors that paved the way for the Mongol invasions, including the absence of a central, unified leadership in the Muslim world, reflected in the demotion of the Abbasids to traditional figureheads who at best could hire mercenaries and conduct assassinations in pursuit of their aims, and increasingly dynamic population movements and expansion by the Turkic tribes of Central Asia.

Juvaini attributed the catastrophe to a number of mistakes of the Muslim rulers and elites, as well as the normal Muslims (particularly traders) for their fraud and wickedness of numerous kinds (he begins the narrative of the causes of the invasion with the attempt by Muslim merchants to swindle Chengis Khan). A general lack of a civilizational ethos given by Islam and other ideologies in other times and places is reflected by the widespread alcoholism among the elites cited by Juvaini. This is one of many examples of references of wine in Persian culture during the autumn of the Abbasid era, but it should be borne in mind that many literary cases wine is used as a cultural metaphor reflecting forgetting the troubles of the world. There were certainly plenty of troubles among the people of Central Asia prior to the Mongol attack invasion [24].

\section{A. Mongol Strength}

The chief characteristics comprising the formidable strength of the Mongols are well recorded. On a fundamental level, it is obvious that the Mongol forces were not conventionally superior to those they defeated - mainly the Chinese and the Muslims of Central Asia. Their siege-craft were primitive - their catapults collapsed at Otrar, which ultimately fell after an extensive siege. The crucial benefit the Mongols possessed lay in combating superiority of their 
soldiers, their strategic advantage and their logistical organisation. We may simply say that the Mongol armies were "better led, organized, and disciplined than those of their opponents." Organization was certainly fundamental, and Juvaini recorded the effectiveness of the Mongol nerge in the following observations:

Now war - with its killing, counting of the slain and sparing of the survivors is after the same fashion, and indeed analogous in every detail, because all that is left in the neighbourhood of the battle are a few broken down wretches [25].

The Mongol troops had a strict code of discipline and harsh penalties for infringements of regulations. The Mongol hordes were divided in units of 10, 100, 1,000, and 10,000 soldiers (known as an arban, jagun, minghan and tümen respectively; the latter corresponds to a modern regiment). Under this system fighters from different tribes were united in unified military formations, whose chief strategy was to "march divided, attack united," and the strategies used were based on large-scale skirmish manoeuvres that helped the Mongols defeat numerically superior but fragmented forces from the Oxus to the Volga [26].

\section{B. The Invasion}

In addition to their logistical and conventional strength, the most overlooked feature of the Mongol invasion is their sophisticated use of intelligence. Having perceived the military weakness of the Khwarezmids in the initial skirmish marshalled by Jebe, whatever perception the Mongols once had of Muslim invincibility and greatness was gone. Additionally, Chengis was aware of the societal divisions and weaknesses in the Muslim camp, and the Mongols disseminated misinformation and subterfuge from the inception of the campaign. Chengis had Islamic advisors who told him for example that the Khwarazm-Shah was deeply unpopular, that he could not convincingly inspire a jihad, and that appeals could be made to his mother to oppose her son. Thus the initial operations of Chengis were psychological; he proclaimed support for the citizens suffering from the oppression of the Khwarazm-Shah, and offered his mother the throne if she collaborated. Additionally, Muslim heralds were typically sent to implore towns and cities to surrender, as at Otrar and Herat, and Turcomen collaborators who knew the roads of the region guided the Mongol armies. These local guides were representative of the snowballing effect of the Mongol army, which immediately recruited experts and levied troops from the vanquished. Chinese siege engineers were quickly joined by Uighur and Kara-Khitai troops en route to the Khwarezmid Empire, and thereafter were joined by the inhabitants of the region itself; with tragic irony, troops levied from Bukhara were part of the assault on Samarqand [26]-[28].

It is commonly assumed that the Mongols simply overwhelmed Transoxiana and Khurasan by their sheer numbers; this is not true. The Mongols suffered heavy losses in their lengthy siege of Otrar - essentially the doorstep of the region from the Mongols' perspective - and they were outnumbered on several occasions. Given the casus belli, the Mongols naturally advanced on Otrar first in September 1219, but were bogged down by the defensive walls and the city only fell after a length siege of six months. However, Chengis simply left a force there (including Chinese siege engineers and Uighur Muslim allies) and took the rest of his forces in the direction of Bukhara. The formation of massive armies that subsequently split at geographical junctures was to form the pattern of Mongol campaigns on a macro-level. In this sense, although a well-fortified city like Otrar could withstand a siege for months, it should be recalled that the cities of Central Asia were not conquered one by one, as several cities and towns were under attack simultaneously. Classical narratives therefore typically focussed on particularly notable engagements - as at Otrar and Herat - or on key cities, such as Bukhara and Samarqand [27]-[29].

It would be unfair to state that the Khwarazm Shah had not prepared for war; Juvaini referred to the perception that he had "passed a lifetime in Holy War", and he had engaged in arduous campaigns against the Kara-Khitai among others whom he considered to be Turkic barbarians menacing the Islamic lands. However, the long-term neglect of defence in the region, originating in the trade-loving inhabitants' dislike of taxes (as when they compelled the Samanids to allow mighty defensive structures to fall into disrepair), meant that the region was not on a footing for a serious war. Nevertheless, the Shah's miscalculation was to presume that he could shelter in mighty citadels while the savage Mongol hordes (whom he viewed with contempt, as revealed in his missive to Jebe) would swarm over the lands of the Khwarezmid Empire, ineffectually burning some crops and villages, then depart due to lack of supplies; in short, it can be inferred from his actions that the Shah presumed that he and his people could weather the storm behind their walls. He failed to take into account two key features of the Mongol military machine: their advanced system of hunting and foraging (explored above) and travelling with livestock, which meant that their nomadic society was continually producing the resources it needed (meaning that the Mongols had the advantage in lengthy sieges); and the incorporation of subjugated peoples, the most important of whom were the Chinese siege engineers and peripheral Turkic (and often Muslim) collaborators, such as the Uighurs and Kara-Khitai, drafted into Mongol military service. The former could reduce the fortresses with gunpowder and mining techniques, while the latter provided intelligence about the inhabitants of the region and were probably involved in the administration of the region from the initial invasion itself (i.e. as translators and commissariat officials) [27]-[29].

This explains the abject failure of the Khwarazm Shah's dispersal and retrenchment strategy in general, as criticized by his son. As for the heart of the Khwarezmid Empire and its armies, Samarqand, to which Chengis turned after the desolation of Bukhara, was arriving there in March 1220. Chengis guaranteed 50,000 scholars and nobles protection if they defected, which many did. Samarqand fell after a siege of only 10 days; at some point the Shah fled and urged others to flee. He himself went to Nishapur to lead a life of dissipation (as narrated by Juvaini), but his son Jalal Al-Din went south and continued warring against the Mongols [29].

The fall of Samarqand marked the de facto end of the Khwarezmid Empire and signalled the complete victory of the Mongols over the Muslims of Central Asia, thus this 
particular Mongol victory was very important. As for 50,000 scholars, nobles and other defectors who joined the Mongols, their grievances against the Khwarazm Shah are well known (as explored previously), thus it could be argued that it was reasonable for them not to wish to die in a last stand defending the greatest stronghold of the Islamic lands of Central Asia.

The pattern was replicated throughout the conquest. When Chengis marched on Balkh in 1221, the scholars and nobles of that prosperous city came out to present the Khan with gifts in the hope of being spared. There is disagreement as to the fate of the collaborators of Balkh, as Juvaini maintained that the inhabitants were ruthlessly slaughtered, while Ibn Al-Athir believed the Mongols spared them; it was described shortly afterwards as a ghost town [24], [30].

Two elements of the Khwarezmid Empire can be cited as examples of Muslim resistance to the Mongols: the city of Herat, and the person of Jalal Al-Din and his followers. The initial Mongol emissary to Herat was killed in contempt, and after the Mongols conquered the city and departed, leaving a malik and political agents; the inhabitants later killed both, refusing to be subdued. Chengis later sent a punitive expedition of 80,000 men to slaughter the people of the city, but a rugged band of survivors still refused to submit to the Mongols and conducted a guerrilla war against them. At times they were so destitute they were reported to resort to cannibalism, but otherwise they were reported to wear silk and live on sugar, the booty from raiding the Chinese caravans. As for Jalal Al-Din, after his father's death in 1220 (hiding on an island in the Caspian Sea), he adopted the Turkic title of Sultan rather than the Persian "Shah," and rallied remaining Khwarezmid troops (presumably Turks, perhaps with some Tajiks and Perso-Sogdians) and recruited new ones in the mountains of the Hindu Kush. With a coalition including Afghans and Pashtun tribesmen, Jalal Al-Din inflicted the first defeat on Chengis Khan's armies at the Battle of Parwan in 1221. The enraged Great Khan then pursued the exhausted Khwarezmid forces to the Indus, where they fell upon the Muslim evacuation and destroyed the army. Jalal Al-Din himself famously leapt into the Indus, astonishing the Mongols, and spent the rest of his life in warfare against the Mongols; he was certainly the most persevering, and perhaps the bravest man of the century [31]-[34].

\section{CONCLUSION}

The reasons for the Mongol invasion can be reduced to a single cause: Muslim weakness. Of course this umbrella term covers an array of factors, but it should be stressed that it does not refer to the material weakness of Muslim civilization and arms in comparison to the Mongols; rather this is one aspect of the essence of the phenomenon, the failure of the Muslim community in the centuries preceding the invasion, and immediately prior to it, to form a unified and constructive state. Mongol propaganda was so successful that its messages endure to the present day, and fundamentally the psychological impact of the Mongol invasion was the decisive component in their victory (rather than material or military superiority, which were important but not sufficient in themselves to inflict such a wholesale humiliation on Central Asian civilization).

The disintegration of the Seljuqs left a vacuum and an absence of effective leadership for the Muslim East as a whole. Disunity between rival dynasties made this prosperous region ripe for invasion by the Mongols, fortified by Chinese military technology and psychological operations tailored to the Muslims; the Mongol 'hordes' were astonishingly sophisticated in their use of advanced weaponry, siege tactics, logistical strategy and intelligence. Conversely the haughty Muslim elites fundamentally miscalculated the advantages of their own material strength and the abilities of the Mongols. Furthermore they had removed any credible basis upon which they could appeal to Islamic sentiments for an Islamic jihad against the Mongol invaders.

\section{REFERENCES}

[1] Encyclopedia Britannica. [Online]. Available: http://search.eb.com/eb/article-73531

[2] H. R. Gibb, The Arab Conquests in Central Asia, New York: AMS Press, 1970, pp. 2-3.

[3] A. J. M. J. Tabari, Tarikh al-Rusul w'al-Muluk, M. J. de Goeje Ed., Leiden: Brill, 1964, pp. 2686-2688.

[4] A. H. A. D. Dinawari, Al-Akhbaral-Tiwal, A. M. A'mir Ed., Brill, 1888, vol. V, pp. 126-127.

[5] S. M. A. Nadvi, Tarikh-i-Islam, Lahore: Maktaba Daniyal, 2006, vol. I-IV, pp. 127-136.

[6] A. S. Najeebabadi, The History of Islam, Riyadh: Darussalam Int'1 Publishers \& Distributors, 2000, vol. I, pp. 363-367.

[7] A. B. Muhammad et al., The History of Bukhara, R. N. Frye Ed.,, Cambridge, Massachusetts: The Mediaeval Academy of America, 1954, p. 38 .

[8] D. Sourdel, The Cambridge History of Islam, Cambridge: Cambridge University Press, The Abbasid Caliphate, 1970, vol. 1, pp. 123-125.

[9] T. W. Marley, The Mongol Invasion and Occupation of Central Asia, 1200-1260 CE: An Islamic Analysis, unpublished thesis, IIUM 2012, p. 50.

[10] The Secret History of Mongol Dynasty, Eng. trans. Yuan-Chao-Pi-Shi, Aligarh: Department of History, AMU, 1957, p. 9.

[11] R. Fadlullah, Jamiut Tawarikh, E. Blochet Ed., London and Leiden: Luzac and Brill: Gibb Memorial Series, 1912, p. 898.

[12] U. B. Mirza, Tarikh-i-Arba-Ulus, Abridged version, Shajratul Atrak, Eng. Trans. by Col. W. Miles, London: Wm. H. Allen \& Co. 1838, pp. 62-64.

[13] The Secret History of Mongol, 1957, pp. 61-65.

[14] B. Spuler, History of the Mongols, Based on Eastern and Western Accounts of the Thirteenth and Fourteenth Centuries, New York: Dorset, 1972, pp. 17-18.

[15] The Secret History of Mongol, pp. 77-78.

[16] History of the Mongols, Spuler, pp. 18-19.

[17] A. D. A. M. Juvaini, Genghis Khan: The History of the World Conqueror, Eng. trans. John Andrew Boyle, Manchester: Manchester University Press, 1958, pp. 64-65, pp. 78-80.

[18] I. H. Siddiqui, "Indian sources on central asian history and culture 13 the to $15^{\text {th }}$ century A.D," Journal of Asian History, 1993, vol. 27, no. 1, pp. 51-63.

[19] A. S. Najeebabadi, The History of Islam, Riyadh: Darussalam Int'1 Publishers \& Distributors, 2000, p. 344.

[20] V. Minorsky, Hudud al-Alam 372A.H.-982 A.D., London, W.C: E.J.W. Luzac \& Company Ltd, 1970, pp. 102-122.

[21] J. A. Boyle, The Mongol World Empire, 1206-1370, London: Variorum Reprints, 1977 edition, IV, p. 616.

[22] P. Ratchnevsky, Genghis Khan: His Life and Legacy, Eng. trans. T. N. Haining, Oxford: Oxford University Press, 1991, pp. 118-119.

[23] S. M. A. Nadvi, Tarikh-i-Islam, Lahore: Maktaba Daniyal, 2006, vol. I-IV, p. 145.

[24] A. D. A. M. Juvaini, Genghis Khan: The History of the World Conqueror, Eng. trans. J. A. Boyle, Manchester: Manchester University Press, 1958 , pp. 77-78, pp. 379-381. 
[25] T. T. Allsen, Mongol Imperialism: The Policies of the Grand Khan Möngke in China, Russia, and the Islamic Lands, 1251-1259, Berkeley, Cal.: California University Press, 1987, p. 29.

[26] Khwandamir, Habibus-Siyar, Tome Three, Eng. trans. \& edited by W. M. Thackston, Cambridge, MA: Harvard University Press, 1994, p. 15.

[27] A. D. A. M. Juvaini, Genghis Khan: The History of the World Conqueror, Eng. trans. John Andrew Boyle, Manchester: Manchester University Press, 1958, pp. 81-6, P. 98.

[28] T. T. Allsen, Mongol Imperialism: The Policies of the Grand Khan Möngke in China, Russia, and the Islamic Lands, 1251-1259, Berkeley, Cal.: California University Press, 1987, p. 6.

[29] P. Ratchnevsky, Genghis Khan: His Life and Legacy, Eng. trans. T. N. Haining, Oxford: Oxford University Press, 1991, p. 131.

[30] A. D. A. M. Juvaini, Genghis Khan: The History of the World Conqueror, Eng. trans. J. A. Boyle, Manchester: Manchester University Press, 1958, pp. 130-133.

[31] J. A. Boyle, The Mongol World Empire, 1206-1370, London: Variorum Reprints, 1977 edition, IV, p. 617.

[32] A. D. A. M. Juvaini, Genghis Khan: The History of the World Conqueror, Eng. trans. J. A. Boyle, Manchester: Manchester University Press, 1958, pp. 130-131.
[33] P. Ratchnevsky, Genghis Khan: His Life and Legacy, Eng. trans. Thomas N. Haining, Oxford: Oxford University Press, 1991, p. 134.

[34] A. S. Najeebabadi, The History of Islam, Riyadh: Darussalam Int'l Publishers \& Distributors, 2000, p. 345.

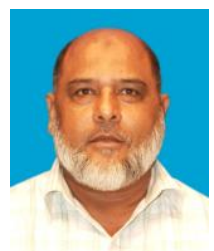

Arshad Islam was born at Azamgarh, India, $\mathrm{He}$ is an associate professor, who holds B.Sc. and M.A. degrees from Gorakhpur University, and M.Phil. and Ph.D. from Aligarh Muslim University, India. At present, he is the chair of Department of History and Civilization at the International Islamic University Malaysia. He joined International Islamic University Malaysia in 1991 and has taught a number of courses in Southeast Asian history, Indian history, history of science, islamic history and civilization, rise and fall of civilizations, and Central Asian history. His research interests include the Malay Sultanates, the coming of Islam to South and Southeast Asia, and Central Asian history. 